Paper presented at the International Association for the Study of the Commons biannual global conference,

Edmonton, Canada, 25-29 May, 2015.

The authors agree to allow the Digital Library of the Commons to add this paper to its archives for IASC conferences.

\title{
The innovation commons - why it exists, what it does, who it benefits, and how
}

\author{
Darcy Allen \& Jason Potts \\ School of Economics, Marketing \& Finance, RMIT University, Melbourne, Australia \\ jason.potts@rmit.edu.au
}

\begin{abstract}
We propose a new type of commons - an 'innovation commons' - that is an emergent institutional solution to 'the innovation problem' (defined as a collective action problem, not a market failure problem). In an innovation commons entrepreneurs pool innovation resources (i.e. inputs into the innovation process) under defined access and governance rules. Innovation requires entrepreneurship, which requires information about market opportunities. This information has interesting characteristics that lend itself to becoming a common pool resource: it is dispersed about the economy; difficult to value in its parts; and largely produced through experiment and experience. Moreover, this information resource fits poorly in institutions of markets or states because uncertainty renders them comparatively costly. We show how the innovation commons solves this problem as a temporary institution that forms around a particular new idea at the very beginning of an innovation trajectory where uncertainty is highest.
\end{abstract}

Keywords: innovation problem, entrepreneurship, commons, uncertainty

\section{Introducing a new commons}

This paper introduces a new species of commons that can be observed in the institutional space of the origination and production of new ideas and technologies and their subsequent application (i.e. adoption and diffusion, Rogers 2003) - which is to say in the context of innovation: hence, innovation commons. The resources that are pooled in the innovation commons - and which constitute the common pool resource - are inputs to the innovation process. At first sight, the innovation commons seems similar to a natural resource commons (Ostrom 1990) - in that there are pooled physical resources, such as research equipment - as 
well as both a cultural commons (Madison et al 2010) and a knowledge commons (Ostrom and Hess 2007, Frischmann et al 2014) - in that it is a cultural process to cooperatively produce new knowledge. So it would seem that an innovation commons is just another addition to the growing list of 'new commons' (Hess 2008).

However, all is not as it seems, and the innovation commons, as we will elaborate in this paper, is a particularly exotic variety of commons. The first thing that is different are the resources in the commons, which are actually composed of two distinct types of resource: the first and most obvious being technical knowledge (and associated physical resources) that describe the new idea or technology. A patented scientific discovery is a typical example. Most innovation policy is concerned with this.

But there is also a second type of resource in the innovation commons that to the uninitiated is largely invisible: namely the distributed bits of information that taken together help define the entrepreneurial opportunity associated with that new technical idea. This is the information that is necessary to develop business models, establish firms, attain financing and write contracts, and ultimately to construct a market and an industry, and which is often widely distributed, difficult to value in its parts, only meaningful when assembled, mostly arrived at through experiment, but without which a new technical idea is basically valueless.

Innovation in other words means a new idea or technology plus its development so that it is adopted and used by many. There are thus two discovery processes involved in innovation: a technical discovery (the science and technology part) and a market discovery (the entrepreneurs, firms and markets part). The first part is invention, which only becomes innovation when coupled with the second part. We argue that the innovation commons is often portrayed as being about the former (for example in the open innovation approach), but we suggest it is actually much more about the latter.

If we are right about this, it gives the innovation commons some peculiar but predictable characteristics. First, it is not essentially about peer production (á la Benkler 2006 , et al) but rather about pooling information to overcome entrepreneurial uncertainty. Which then implies, second, that once that uncertainty is overcome, and entrepreneurs can confidently act, we should expect the innovation commons to collapse. An innovation commons, unlike natural resource commons or many other new commons, will be a transient and temporary institutional phenomenon. And thirdly, following from this, the innovation commons will then give way to other institutional forms that address the incentives to innovation.

The significance of the innovation commons, from the perspective of the more general study of the commons, is that this is a new and exotic commons that has not been well explored, yet is likely to have played an important role in the shaping modern economic growth and development. So this is a new research domain. But from the perspective of innovation economics and innovation policy, there is the prospect that by systematically overlooking the role of the innovation commons we have fundamentally misrepresented the institutional logic of the innovation process. We think this is actually the case, which suggests that a commons based approach might help us to better understand the theory of the innovation process and to develop better innovation policy. 


\section{The innovation fallacy}

A great deal of thinking about the nature of the innovation problem - both in theory, and in its applications, including policy_is marred by what we call 'the innovation fallacy'. This is a fallacy in the sense of an argument that appears to be correct, but actually isn't so. The fallacy relates to what is understood to be a solution to the innovation problem of supposedly sub-optimal directing of investment towards innovative activities.

The so-called 'innovation problem' (Arrow 1962) is conventionally conceived in relation to the economics of producing new information in a competitive market context: how to incentivize private investment and allocate public investment in innovation? This matters because the novel outputs arising from these investments are widely understood to propel economic growth and wealth. Two separate input components are needed to successfully solve the innovation problem. The first part is investment (usually called research and development, or R\&D) in a new technology. This is the technical phase of innovation and is usually undertaken by scientists and engineers and the like. The second part is the adoption and diffusion process that occurs through firms and markets. This is the entrepreneurial phase of innovation that is driven by market opportunity. Both of these problems are discovery problems; the scientist discovers a technology, the entrepreneur discovers a market opportunity. But these are fundamentally different discovery problems. And the attention of innovation academics and policymakers has largely been on only the technical phase of innovation.

The innovation fallacy is the belief that the innovation problem is solved entirely in the first phase; the technical phase. This phase is where the market failure is nominally identified (Nelson 1959, Stephan 1996, Martin and Scott 2000, Bleda and del Rio 2013). But focusing solely on the technical phase of this problem is tantamount to arguing that entrepreneurship and the experimental market process is a free good. This is not the case. The process of discovering and exploiting market opportunities is a costly process. It is costly because it is also riddled with and fundamentally characterised by uncertainty.

Innovation policy centred on market failure ignores the role of alertness (Kirzner 1978) and judgement (Knight 1921, Foss and Klein 2012) of the entrepreneur. Schumpeter (1934) recognised that there is a difference between invention and innovation. Invention is about creating new things; innovation is about creating new things that the market wants to buy. Invention creates little - if any - consumer or producer surplus, or economic effect. It is only when both the technical and the entrepreneurial aspects of innovation are coupled that innovation may open up the potential societal transformations and externalities that innovation catalyses.

We will argue in this paper that solving the innovation problem involves solving both a technological discovery problem and a market discovery problem. We emphasize that the societal value of new ideas and technology is realized only when both problems are solved, and that in general the second problem of entrepreneurial market discovery is no less complex and difficult than the first scientific technological discovery problem. This 
entrepreneurial problem is about taking technological potential and filling in all the missing information about: possible uses; by whom; at what price points; under what business models; produced and distributed in what ways; with what costs and sources of supply; with what complementary investment; and subject to what competition; what regulatory and political barriers; with what public support or taxes; under what constellation of comparative advantages and economic externalities; and so on. The entrepreneurial information described above is necessary to identify, discover or create an entrepreneurial opportunity (Casson 1982, Singh 2000, Shane 2000, Shane and Venkataraman 2000, Foss and Klein 2012). Both technological-scientific discovery and entrepreneurial-market discovery must be necessarily and successfully coupled for a complete solution to the innovation problem.

The innovation fallacy is the belief that once you've solved the scientific problem of creating new technical knowledge, and perhaps patenting it, that you've solved the innovation problem (a high-profile recent example is Mazzucato 2013). This is the fallacy that the science and technology part of the discovery process is both necessary and sufficient; which is equivalent to believing that the market will take care of the rest with relatively costless ease, or that entrepreneurial resources are free goods. By succumbing to the innovation fallacy, our innovation system misunderstands the institutional role of the innovation commons. We propose that the emergent institution of the innovation commons is where agents cooperate to pool information in order to discover entrepreneurial opportunity. Without understanding the innovation fallacy, the existence of the innovation commons appears to be an anomaly. But it is not. It is an efficient institutional solution to the collective action problem of dealing with uncertainty.

\section{The innovation problem - Beyond firms and states}

The innovation problem is caused by misaligned microeconomic incentives. As a society we collectively do well if private resources are allocated to the innovation process; the positive externalities associated with innovative activity are well known. But as individuals we are better off if someone else undertakes the process because it often involves high fixed costs and financial risks. And because these sunken costs are hard to appropriate - due to the public good nature of ideas - there may be private reluctance to invest in the innovation process (Arrow 1962). The innovation problem is generally discussed from a social welfare perspective. The basic problem here is that the social return to $R \& D$ is greater than the private return (Jones and Williams 1998). That is, as a mismatch between private resources devoted to the supply of innovation and some arbitrary socially desirable level. It is widely held in economics that a frictionless competitive market will allocate sub-optimal resources towards innovative activities (Nelson 1959, Romano 1989). This is the diagnosis of 'market failure' (Bator 1958) in the production of new ideas.

Market failures in innovation are swiftly followed by calls for government intervention to ameliorate the problem. That is, the underinvestment in innovation is used to justify state intervention (Martin and Scott 2009). This consensus view is the basis of innovation policy: government intervention is required to bring the level of resources devoted to innovation up to the socially optimal level (i.e. that which accounts for all the positive 
externalities and other market failures). What has emerged is an ever-growing suite of interdependent innovation institutions that collectively constitute innovation policy (Nelson 1993, Freeman 1995, Soete et al 2010, Dodgson et al 2011). All attempt to solve the same long-running economic problem of how to incentivise private agents to invest in innovation by re-aligning their incentives. They do this through two broad categories - market-based interventions or planning-based interventions (Bleda and Del Rio 2013) — that may be arrayed along a spectrum. On one end sits market based intellectual property statues providing monopoly rights over innovations, and enforced through legislative and judicial branches. This Coasian solution attaches property rights so that innovation may be bargained to equilibrium (Coase 1960). At the other end of the spectrum are government created and directed non-market organisations - including public science institutes - based on top-down planning and control. Intermediate between these extremes of market and state institutions are hybrid mechanisms operating through both markets and planners. The most common of these are Pigouvian subsides - such as R\&D tax credits - where an externality is identified by the state and a subsidy is applied to correct it.

There are different costs and benefits at different margins associated with each innovation institution (Goolsbee 1998, Davidson and Potts 2015). Both the benefits and costs of innovation policies are not widely understood. All of these institutions are socially costly from a comparative institutional perspective (Shleifer and Vishny 2002, Djankov et al 2003, Boettke et al 2005, Davidson and Potts 2015). For example, the intellectual property system generates a trade-off between static and dynamic efficiency by constraining the future use of that innovation and information (Boldrin and Levine 2002, 2005, 2013). Moreover, what are often ignored are the direct and indirect costs of government failure and regulatory capture (Stigler 1971, Krueger 1974). These failures include rent-seeking (Murphy et al 1993, Goolsbee 1998, Boldrin and Levine 2008), the identification of externalities (Davidson and Spong 2010) and agency problems (Holstrom 1989). Elinor Ostrom (2005) repeatedly argued that institutional diversity is a worthy goal, and especially so when we don't know what the right institutions are. There is scant evidence to suggest that we have got the innovation policy institutions right. As with institutions governing the use of natural resources, there is no panacea when it comes to the institutions of innovation policy. Yet there remains a widespread presumption in academic work on innovation policies that the state will succeed where the market is assumed to fail.

This commonality of state-intervention across the entire spectrum of innovation policy is not at first obvious. This is because many of the institutions seem to be marketbased. On closer inspection however all of these policies are inescapably tools of government intervention to some degree, even intellectual property, which is at base a government granted monopoly (Boldrin and Levine 2008). This assumption is rarely challenged or questioned in economic theory, or more specifically in innovation policy (Boldrin and Levine 2004, Davidson and Spong 2010, Lindsay and Dougan 2013, Davidson and Potts 2015), even though there are many historical examples that illustrate the contrary (Nuvolari 2004, Boldrin and Levine 2008). 
The 'innovation problem' has a similar contemporary status in economics to Hardin's (1968) parable of the tragedy of the commons. While the specific problem differsfrom under-produced innovation resources to over-exploited natural resources - the underlying treatment remains the same. Both begin with a supposed failure of civil society to produce an efficient due to misaligned individual and group interests. Both end with calls for corrective state intervention in several dimensions. These solutions sit on the familiar dichotomy of markets and states. Yet there is a growing body empirical works studying how different resources - including natural, knowledge and cultural - may be pooled over common property and maintained and shared by the community (Ostrom 1990, Hess and Ostrom 2006, Madison et al 2012, Frischmann et al 2015). This literature teaches that collective action and civil society self-governance may be effective institutional solutions to the problems actors face. The underlying theme is that 'commons' institutions may actually outperform their private or public alternatives.

Just as Ostrom (1990) claimed privatisation and government-control solutions are 'too sweeping in their claims', so too for the governance of innovation resources. Just as the tragedy of the commons was misdiagnosed for natural resources, innovation policy has also been misdiagnosed. There is a potentially mistaken suite of government remedies under innovation policy. We need to move beyond markets and states in the governance of innovation resources. An innovation commons exists where private actors pool innovation resources - these resources can be multiple, but include not just technical knowledge but also entrepreneurial knowledge about market opportunities - under collective action governance rules.

To explore innovation commons we will separate two specific aspects necessary for their understanding: entrepreneurs as the actors; and the biophysical characteristics of the resources they require. ${ }^{1}$ Drawing on the 'innovation fallacy' section 4 explores the problem the entrepreneur faces, the concept of market opportunities, and the characteristics of these resources. Section 5 describes the innovation commons and its characteristics, and furnishes some theoretical explanations for their emergence.

\section{Entrepreneurs, market opportunity, and innovation resources}

\section{The entrepreneur}

The entrepreneur is an agent tasked with making decisions and coordinating resources in the face of fundamental uncertainty. As far back as Cantillon (1775) the entrepreneur has been characterised as a specialised risk taker who allocates and transforms scarce resources. In early works the entrepreneur was also commonly described by their personality-daringness, wit, intelligence and so on - rather than their functionality. It was not until the early $20^{\text {th }}$ century that the entrepreneur became recognised as an economic driver of change. Joseph Schumpeter (1912) described the entrepreneur as an agent who introduced novelty, newness

\footnotetext{
${ }^{1}$ These are loosely centred on two specific areas of the Institutional Analysis and Development (IAD) framework (see Ostrom 1990, 2005; Hess and Ostrom 2007, Madison et al 2012, Frischmann et al 2014)
} 
and change to economic life. However this role of the entrepreneur in generating economic growth did not fit well into the mainstream economic models. ${ }^{2}$ Instead, it was the Austrian economists - and their focus on dispersed knowledge, uncertainty and institutions - who theorised entrepreneurs as agents: (1) acting in an environment of uncertainty; (2) exhibiting some kind of judgement, alertness, or skill in making those decisions; and (3) acting to coordinate or allocate scarce resources based on those judgements. ${ }^{3}$

In this view, uncertainty is fundamental to entrepreneurship and to innovation. Innovation is production where you don't quite know what it is you're producing, or exactly how you're going to do it, until you do it (Stark 2009). Entrepreneurs are the agents who navigate that space. It is a process riddled with uncertainty, not a simple task of rational optimisation on inputs and outputs. Entrepreneurs cannot simply weigh all of the given alternatives, understand the entire multitude of payoffs, and choose optimally, as if in an environment of probabilistic risk. Following Knight (1921), risks are events over which a probability distribution may be attached. Uncertainty, on the other hand, is about unique events over which outcomes are not only unknown but fundamentally unknowable. ${ }^{4}$ This is the true problem of entrepreneurship: making decisions over events with few, perhaps no, similar past events on which to base expectations. The entrepreneur faces uncertainty not risk. Entrepreneurship is about creating or identifying new ends and means relationships that were previously undetected or underutilized by market participants (Gaglio and Katz 2001, Erckhardt and Shane 2003). ${ }^{5}$ Thus competition between entrepreneurs is a game of who can first make decisions ex ante of markets that become good decisions ex post. However the entrepreneur must make decisions today while the potential profits or losses will only be realised in some future time period. The entrepreneur is making decisions where the relevant information will only exist once the market has been successfully created (Arrow 1962).

The entrepreneur's problem is that of dealing with, acting on, and reducing uncertainty. The task of the entrepreneur is to discover, create or eliminate potential market opportunities where decision outcomes cannot be known ex ante. Entrepreneurs face illstructured problems of search and discovery of market opportunities (Dosi 1988), and consequently those who correctly identify the value of innovation resources and other market factors will be rewarded with profit (Kirzner 1973). The inputs into this process - innovation resources - are resources that entrepreneurs may acquire to deal with this uncertainty in order to discover market opportunities (Shane and Venkataraman 2000).

\section{Market Opportunities and Innovation Resources}

\footnotetext{
${ }^{2}$ Thus when the entrepreneur is added to mainstream models they are generally added as a fourth factor of production alongside land, labour and capital (Endres and Woods 2014)

${ }^{3}$ For example see Mises (1949), Shackle (1992), Kirzner (1978), Casson (1982), Schultz (1980), Foss and Klein (2012), and Earl (2003).

${ }^{4}$ See Kirzner (1997), Lachmann (1976) and Shackle (1979).

${ }^{5}$ Uncertainty is a two-sided coin for the entrepreneur as both the problem they must overcome, and their source of profit. With perfect knowledge and foresight there would be no entrepreneurial profit, as all market opportunities would be costlessly and instantaneously exploited (Knight 1921, Rumelt 2005).
} 
Invention creates new things; entrepreneurship creates new things that are economically viable. These are different endeavours, and only the latter involves considering market opportunities. The former is the task of the inventor, scientist, engineer, or the like. The second is what the entrepreneur does. We now consider the nature of those entrepreneurial opportunities, the resources entrepreneurs require to discover those opportunities, and the characteristics of those resources. ${ }^{6}$

The entrepreneur is boundedly rational. They can never access nor process, within any reasonable time frame or cost, the complete set of information that would be needed to perfectly assess a market opportunity in respect of how a technology works in particular circumstances; the potential regulatory barriers and political uncertainty they may face; the way consumers use the technology in differing circumstances; the price points of competing technologies; the forward marginal costs and revenues of production; the sourcing of physical resources for production; the prospect of potential investment including venture capital; the problems that may arise when scaling up; the sources of expertise which they may seek and purchase; and so on. Obviously they would seek to gather that information, and its possession would be exactly as valuable as the opportunity it represents. Yet for the most part, this information is inherently unknowable ex ante. They are within a cloud of uncertainty.

However, potential entrepreneurs may improve their situation, and boil off some of this uncertainty, by accessing information held by others. While no one person may have all that information, many people might - which is to say that the information sufficient to describe the opportunity is distributed. Profit opportunities exist because different individuals hold different sets of local knowledge. If the economy were to be characterised by homogenous and perfect sets of knowledge then there would be no need for entrepreneurship because no market opportunities would exist (Shane 2000). Just as different entrepreneurs will discover different opportunities because they possess different prior knowledge (Venkataraman 1997), entrepreneurial agents may seek to reciprocally pool their knowledge - i.e. I'll show you mine if you show me yours - in the hope of mutually discovering a market opportunity.

To the entrepreneur this furnishes an important possibility: the prospect of coordinating heterogeneous knowledge about market opportunities. In this way, the entrepreneur attempts to generate probability sets of other tested market opportunities that might transform uncertainty into something resembling more manageable risk. While the entrepreneur can never know the ex ante value of an idea, technology or innovation (this can only be revealed by the market), they may inform their estimation of a market opportunity by assembling the distributed information of other agents. The pieces of knowledge that in total describe a market opportunity are distributed over many agents in an economy. Information about the sort of business models to be developed, or distribution channels to be identified, or understandings of specific potential regulatory barriers - very rarely exists within a single

\footnotetext{
${ }^{6}$ The entrepreneurship literature variously describes opportunities as being: recognized by aligning demand and supply to exploit existing markets (e.g. arbitrage); discovered by exploring existing and latent markets and matching up; or created where supply and demand do not exist in an obvious manner and new markets must be created (Sarasvathy et al 2003). We will encompass this all as 'discovery', as in the discovery of knowledge about market opportunities.
} 
mind in a concentrated or aggregated form (Hayek 1945, Shackle 1972). (Nor does technical knowledge, as Adam Smith first pointed out: it is distributed over many specialised agents.)

This entrepreneurial knowledge is also generally only acquired by experiment and experience. The value of such knowledge only emerges once it has been assembled and combined with other complementary resources. But what is complementary and what is not remains unclear before they are synthesised. Thus, these bits of information exhibit heterogeneous value. This is why many entrepreneurial theories focus on judgement, or synthesis, or making connections.

Prices can do much of this coordinating work, as Hayek (1945: 526) explained: "... in a system where the knowledge of the relevant facts is dispersed among many people, prices can act to coordinate the separate actions of different people in the same way as a subjective values help the individual to coordinate the parts of his plan." But this is mostly a story of the process of equilibrium in markets for goods that already exist, not of entrepreneurship and innovation. Hayek (1945) meant coordination in which prices communicated coordinating information. But there are no contingent prices for future goods and services (Arrow 1974, Erckhardt and Shane 2003). When new markets are being created it is difficult to price this information. Innovation is a problem about new coordination, not re-coordination (Dopfer and Potts 2008). And while the price system is highly efficient in recoordinating extant economic activity, "prices fail to provide information on how new markets could be served, how a new technology could be used to improve a production process, or how a new way or organizing will generate value... [prices do not] accurately guide the discovery and exploitation of entrepreneurial opportunities" (Eckhardt and Shane 2003: 337). It is only ex post that a price may take into account the value innovative value. In other words, as a coordinating institution, the price mechanism does not carry information that relieves entrepreneurial uncertainty. If entrepreneurs cannot use the price system to coordinate the market knowledge they require, then where do they go to get it? The answer lies in the various properties of that information. We elaborate on a number of these here: it is dispersed about the economy; may only be learned through experience and discovered through experimentation; and exhibit heterogeneous and ex ante unknowable value.

This information does not fit well into firms because it translates poorly through the hierarchy mechanism of an organisation (Coase 1960). It does not fit well into markets because prices cannot transmit information about failed or potential ventures (except through

the cumbersome inclusion of expectations). Yet this entrepreneurial information about market opportunities is valuable - so where can it be found? We propose that this information will often form in the innovation commons. Furthermore, cooperation through the pooling of innovation resources more generally - are emergent institutions solving the problem of distributed knowledge about market opportunities for innovation.

\section{The innovation commons}

The innovation commons is an emergent institution of pooled innovation resources collectively governed by entrepreneurs. These rule-governed spaces emerge as solutions to 
the social dilemmas inherent in sharing innovation resources between entrepreneurs. Thus the innovation commons are a solution to the society-wide innovation problem, and they do this through civil society collective action.

There are obvious similarities here with the recent work on the cultural and knowledge commons (Lessig 2004, Benkler 2007, Madison et al 2010, Ostrom and Hess 2007, Frischmann et al 2014). Moreover, there are links to the work on user innovation, democratised innovation, open innovation and collective invention (von Hippel 1986, 2003; Chesbrough 2003, Allen 1983, Nuvolari 2004). But we argue that the innovation commons we describe here are of a fundamentally different character because they are trying to solve a different problem.

The innovation commons are a subset of the knowledge commons. But they are a subset that has an entirely different goal; the innovation commons contain resources dedicated to the advance of knowledge, not simply the aggregation of it. That is, the innovation commons have grown from the niches opened by the broader knowledge commons, but with a different purpose. The innovation commons are also distinct from the current work on peer production and suchlike (Benkler 2006). Peer production is about the production of things, many of which already exist, but through a new institutional form collectively rather than privately or publically. However, the innovation commons is about the production of new and novel things that are fundamentally shrouded in uncertainty in respect of how that will specifically occur. While the innovation commons share a similar set of enabling factors to the knowledge commons - namely new forms of communication, especially social media, leading to falling transaction and coordination costs - they are of a fundamentally different character because of the ongoing presence of uncertainty. Contemporary examples include the enthusiast groups coalescing around 3D printing technology and drones, or the much more widely understood examples of the computer industry. User communities associated with new technologies are also good instances of innovation commons (Franke and Shah 2003).

In this sense, an innovation commons is effectively two commons simultaneously: one of technical and material resources; and another of market information. The first are resources including technical knowledge and capital goods about how to physically make things and is of interest to the engineer or the scientist. The second is the knowledge about market opportunities; the information about the market opportunities of a given innovation that is of interest to the entrepreneur. Innovation requires combining both types of resourcetechnical knowledge and market opportunity knowledge - and therefore we expect that both types of resource may be in the commons - we call this the 'dual commons hypothesis' in which what is being pooled in the innovation commons is both technical resources as well as entrepreneurial knowledge about market opportunity.

Yet while the former is often the most visible, it is the later that is often of the greatest value, as it does not easily supplied by other institutional forms. Private firms tend not to share this, or keep it tacit, and public research organizations do not produce it in the first place. The innovation commons can provide a map of the costs and benefits associated with a new idea or technology, thus reducing uncertainty so as to form the outlines of an 
entrepreneurial opportunity. The innovation commons is thus an institutional mechanism to facilitate the process of entrepreneurial discovery (Hayek 1945; Hausmann and Rodrik 2003; Bakhashi et al. 2011). It is this unique property of furnishing information that reduces uncertainty which then enables entrepreneurs to act in other institutional forms - such as firms and markets, or in the state - that makes the innovation commons not just about social provisioning, or peer production simpliciter.

The innovation commons is somewhat club-like, however, with a cost to enter that is necessary to limit free-riding. This is invariably some contribution of innovation resources that will be of value to the other commoners - which may be physical or information resources, and technical or market information. The initial contribution of innovation resources may act as some screening mechanism for entry into the commons. Thus the innovation commons may look like a club, but be a commons on the inside (á la Polanyi's (1944) the republic of science). An innovation commons based on market information about potential innovations will likely be sustained under collective action governance rules. It is the value of the entrepreneurial knowledge that underwrites the incentives for collective action in the innovation commons.

The innovation commons pools a wholly different type of knowledge compared to a knowledge commons, and does so for a different purpose. An innovation resource pool of market opportunities has a number of interesting properties that stem from the resource itself. First, knowledge about exploiting market opportunities is latent by nature. Its value only exists in the potential future value of exploitable opportunities. The general method to reveal this value is through trial-and-error experimentation. While the different 'bits' of an innovation may have little meaning in isolation, they may possesses immense value to the entrepreneur once the overall pattern can be discerned. A potential entrepreneur with an interest in the prospects of a new idea or technology will enter the innovation commons and contribute to the projects of others. In return he or she will gain bits of information that helps - or renders obsolete - the particular puzzle they are attempting to solve. What this means is that the innovation commons are generally positive sum.

Second, because innovation commons pool information that solves problems by reducing uncertainty, an innovation commons will tend to be temporary and targeted in nature. They are not an economy-wide substitute for other innovation institutions (as the peer-production model of a commons seeks to be, $a$ la Benkler 2006), but rather are a complementary institution that sometimes emerges at the beginning of an innovation trajectory. The value of the innovation commons arises from its comparative efficiency in solving the problem of uncertainty over resource value - and hence uncertainty over market opportunities.

Contrary to natural resource commons - where a commons may be perpetual if the particular set of rules is sustained - innovation commons tend to be temporary, and perpetual only under special circumstances. The reason here is the value of the underlying resource. The resources in an innovation commons are appropriable rules for entrepreneurs to resolve uncertainty over market opportunities. These are pooled for the purpose of revealing opportunities, but are competitively entropic because of that. While the innovation commons 
are born of fundamental uncertainty about innovation opportunities, addressing this problem successfully will collapse the functional rationale for the commons. Uncertainty is what engenders their creation; and the resolution of that same uncertainty instigates their collapse.

Third, the entrepreneurial problem changes throughout time. As above, the value of the innovation commons as an institution is their ability to deal with uncertainty. It is uncertainty that makes the other institutional forms - namely private property - costly. The commons will lose value as this uncertainty declines. Therefore we expect that where uncertainty over market opportunities is high the innovation commons will spontaneously emerge as an institutional solution. In the Schumpeterian model, an innovation trajectory has three phases: (1) entrepreneurial origination; (2) adoption and diffusion; and (3) retention and institutional embedding (Dosi 1982, Klepper and Graddy 1990, Dopfer and Potts 2008)). An innovation commons is thus a zero-th phase that logically forms before the entrepreneurial phase can begin, because it gathers the information necessary for the discovery of the entrepreneurial opportunity from a nascent new idea or technology. This $0^{\text {th }}$ phase is where ill-defined and dimly perceived opportunities are beginning to gather and coalesce.

Interestingly, natural resource commons also often emerge out of uncertainty, but this does not lead to them being temporary, but rather the opposite. A common pool resource will tend to form where there is natural uncertainty about supply of the resource (such as grazing pastures, or a fishery). Private or public property institutions are often inefficient in such circumstances. A commons may thus emerge for the term of the uncertainty, which in the case of nature-generated uncertainty owing to weather or natural resource flows may be indefinite, as a perpetually more effective institution than their market and state alternatives. But the reason for existence of the innovation commons is to reduce uncertainty. Many of the knowledge commons that are cited - open source software (Lerner and Tirole 2005), knowledge repositories such as Wikipedia and alike - are artificially kept in the commons. That is, they are kept in the commons using legal tools such as the Creative Commons suite of licenses. But a naturally occurring innovation commons, as an institution, is expected to disappear once it has performed its uncertainty reducing function (and if it continues, it will only do so if artificially sustained).

In this same way, an innovation commons does not exist across an entire economy, sector or region. Rather, its location is emergent with respect to the social organisation of the development of a technology. These are not general spaces; much of their value comes from their sorting ability in whittling away uncertainty. Thus innovation commons exist on many scales and levels of organisation that are dependent on the resource needs of various entrepreneurs, and on the stage of the industry or market. The innovation commons are predicted to emerge along an innovation trajectory, and within an innovating economy, wherever uncertainty is highest about the pathways through which to develop a new idea or technology. The benefit of the innovation commons is information pooling. For example, this pooling may be about optimal matching of an idea to an innovation institution for further development. That is, some ideas may be better developed in public research institutions, for example-while other ideas may be better developed through the private technology start- 
ups, for example. The innovation commons provides a crucial institutional component in pooling information to make those decisions.

A further reason why the innovation commons is predicted to institutionally emerge at the beginning of an innovation trajectory is defence against enclosure. The innovation commons may in fact act defensively as an institution to minimise the risk that the technology will not find a viable market niche, or that it is locked on a particular path. Technologies and markets exhibit path dependency; the commons provides a mechanism to experiment with the correct path by keeping the pathway open. This mechanism can be observed in the efforts of those committed to open source software to maintain an innovation commons less as a service to potential entrepreneurs, but rather precisely to prevent alternative institutions (in this case private property rights) enclosing the technology and locking it into one particular path of development (von Krogh et al 2013). As an experimental space, the innovation commons may also act to shake-out unintended consequences through facilitating small-scale adoption of a new idea or technology. It does this in a less costly and potentially less risky method than a full product launch or mass deployment. That is, it may be an alternative institution for the 'trial' stage of a technology, where the reciprocal sharing and testing between individuals over common property may fulfil this role. There is an inherent risk from any new markets or being new in any market. The innovation commons may thus emerge as some form of defensive institutional mechanism against entrenched economic interests. The very beginning of an industry, market, or product faces the prospect of political destruction by those who would see it as competition. An innovation commons may thus act as a bulwark against resistance from incumbent technologies and other entrenched interests with rents to protect. But, of course, it is also possible that these innovation commons may later form into rent-seeking interest groups (Schumpeter 1942, Olson 1982).

\section{Conclusion}

Elinor Ostrom (1990) defined a commons as collective action governance mechanism over a common pool resource that was vulnerable to social dilemmas. We have sought to add to the pantheon of commons by describing a commons about innovation resources and entrepreneurs: the innovation commons. This suggests a new research program at the intersection of innovation economics and institutional economics.

Contrary to the foundations of innovation policy — which operates through state intervention in various ways - the innovation commons arise from civil society. An innovation commons is a collective action institutional solution to a fundamental part of innovation problem, namely in pooling information sufficient to reduce uncertainty to enable entrepreneurs to act. It is a remarkably common fallacy among innovation scholars and policy-makers that the innovation problem is solved once the technical or scientific aspect of the innovation problem is solved. But entrepreneurial market information is also required, and this critical resource can be efficiently supplied in the commons. The innovation commons emerge where entrepreneurs pool private innovation resources-namely knowledge about market opportunities — over a common property. The innovation commons 
emerge and are sustained through the value of knowledge about market opportunities. Thus these are rule governed spaced emerging out of civil society, not on the entrenched markets versus states dichotomy of innovation policy.

The innovation commons are temporary institutional spaces because as uncertainty declines the rationale for their existence collapses. They tend to emerge at the beginning of a new idea, technology. And they are not in competition with other innovation institutions (e.g. firms and markets), but tend to be precursors to them. Their existence derives from their greater efficiency as solving a collective action problem of pooling innovation resources to reveal opportunities by reducing uncertainty. We expect that an innovation commons will be a transient institution in respect to innovation systems that will emerge about new ideas and technologies where there are high levels of uncertainty that are inhibiting entrepreneurial action. They will collapse and decompose when that uncertainty is resolved.

\section{References}

Allen, R. C. 1983. Collective Invention. Journal of Economic Behavior and Organization 4(1):1-24.

Arrow, K. J. 1962. Economic Welfare and the Allocation of Resources for Invention. In The rate and direction of inventive activity: Economic and social factors, eds. R. R. Nelson, 609-626. Princeton: Princeton University Press.

Arrow, K. J. 1974. Limited Knowledge and Economic Analysis. American Economic Review 64(1):1-10.

Bakhshi, H., A. Freeman and J. Potts. 2011. State of Uncertainty. Provocation Paper 14:1-19.

Bator, F. M. 1958. The Anatomy of Market Failure. Quarterly Journal of Economics 72(3):351-379.

Benkler, Y. 2006. The Wealth of Networks: How Social Production Transforms Markets and Freedom. New Haven: Yale University Press.

Bleda, M. and P. del Río. 2013. The Market Failure and the Systemic Failure Rationales in Technological Innovation Systems. Research Policy 42(5):1039-1052.

Boettke, P. J., C. J. Coyne, P. T. Leeson, and F. Sautet. 2005. The New Comparative Political Economy. The Review of Austrian Economics 18(3/4):281-304.

Boldrin, M. and D. K. Levine. 2002. The Case Against Intellectual Property. CEPR Discussion Paper No. 3273. Available at SSRN 307859.

Boldrin, M. and D. K. Levine. 2004. Rent-Seeking and Innovation. Journal of Monetary Economics 51(1):127160.

Boldrin, M. and D. K. Levine. 2005. The Economics of Ideas and Intellectual Property. Proceedings of the National Academy of Sciences of the United States of America 102(4):1252-1256.

Boldrin, M. and D. K. Levine. 2008. Against Intellectual Monopoly. Cambridge: Cambridge University Press.

Boldrin, M. and D. K. Levine. 2013. The Case Against Patents. The Journal of Economic Perspectives 27(1):322.

Cantillon, R. 1775. Essai sur la nature du commerce en general.

Casson, M. 1982. The Entrepreneur: An Economic Theory. NJ: Barnes and Noble Books. 
Chesbrough, H. W. 2003. Open Innovation: The New Imperative for Creating and Profiting from Technology. Boston: Harvard Business Press.

Coase, R. H. 1960. The Problem of Social Cost. Journal of Law and Economics, 3(1):414-440.

Davidson, S., and J. Potts. 2015. Social Costs and the Institutions of Innovation Policy. Available at SSRN 2565574.

Davidson, S., and H. Spong. 2010. Positive Externalities and R\&D: Two Conflicting Traditions in Economic Theory. Review of Political Economy 22(3):355-372.

Djankov, S., E. Glaeser, R. La Porta, F. Lopez-de-Silanes and A. Shleifer. 2003. The New Comparative Economics. Journal of Comparative Economics 31(4):595-619.

Dodgson, M., A. Hughes, J. Foster and S. Metcalfe. 2011. Systems Thinking, Market Failure, and the Development of Innovation Policy: The Case of Australia. Research Policy 40(9):1145-1156.

Dopfer, K. and J. Potts. 2008. The General Theory of Economic Evolution. Routledge.

Dosi, G. 1982. Technological Paradigms and Technological Trajectories: A Suggested Interpretation of the Determinants and Directions of Technical Change. Research Policy 11(3):147-162.

Dosi, G. 1988. Sources, Procedures, and Microeconomic Effects of Innovation. Journal of Economic Literature 26(3):1120-1171.

Earl, P. E. 2003. The Entrepreneur as a Constructor of Connections. Advances in Austrian Economics 6:113130.

Endres, A. M. and C. R. Woods. 2006. Modern Theories of Entrepreneurial Behavior: A Comparison and Appraisal. Small Business Economics 26(2):189-202.

Eckhardt, J. T. and S. A. Shane. 2003. Opportunities and Entrepreneurship. Journal of Management 29(3):333349.

Foss, N. J. and P. G. Klein. 2012. Organizing Entrepreneurial Judgment: A New Approach to the Firm. Cambridge: Cambridge University Press.

Franke, N. and S. Shah. 2003. How Communities Support Innovative Activities: An Exploration of Assistance and Sharing Among End-users. Research Policy 32(1):157-178.

Freeman, C. 1995. The 'National System of Innovation' in Historical Perspective. Cambridge Journal of Economics 19(1):5-24.

Frischmann, B. M., M. J. Madison, and K. J. Strandburg. eds. 2014. Governing Knowledge Commons. USA: Oxford University Press.

Gaglio, C. M. and J. A. Katz. 2001. The Psychological Basis of Opportunity Identification: Entrepreneurial Alertness. Small Business Economics 16(2):95-111.

Goolsbee, A. 1998. Does Government R\&D Policy Mainly Benefit Scientists and Engineers? National Bureau of Economic Research Working Paper No. 6532.

Hausmann, R. and D. Rodrik. 2003. Economic Development as Self-discovery. Journal of Development Economics 72(2):603-633.

Hardin, G. 1968. The Tragedy of the Commons. Science 162(3859):1243-1248.

Hayek, F. A. 1945. The Use of Knowledge in Society. The American Economic Review 35(4):519-530.

Hess, C. 2008. Mapping the New Commons. Available at SSRN 1356835.

Hess, C. and Ostrom, E. eds. 2006. Understanding Knowledge as a Commons: From Theory to Practice. Cheltenham: Edward Elgar. 
Holmstrom, B. 1989. Agency Costs and Innovation. Journal of Economic Behavior and Organization 12(3):305-327.

Jones, C. I. and J. C. Williams. 1998. Measuring the Social Return to R\&D. Quarterly Journal of Economics 113(4):1119-1135.

Kirzner, I. M. 1996. The Meaning of Market Process: Essays in the Development of Modern Austrian Economics. Psychology Press.

Kirzner, I. M. 1973. Competition and Entrepreneurship. Chicago: University of Chicago Press.

Klepper, S. and E. Graddy. 1990. The Evolution of New Industries and the Determinants of Market Structure. The RAND Journal of Economics 21(1):27-44.

Kostakis V., V. Nairos and C. Giotitsas. 2014. Production and Governance in Hackerspaces: A Manifestation of Commons-Based Peer Production in the Physical Realm?' International Journal of Cultural Studies 1-19.

Krueger, A. O. 1974. The Political Economy of the Rent-seeking Society. The American Economic Review 64(3):291-303.

Lachmann, L. M. 1976. From Mises to Shackle: An Essay on Austrian Economics and the Kaleidic Society. Journal of Economic Literature 14(1):54-62.

Lerner, J. and J. Tirole. 2005. The Economics of Technology Sharing: Open Source and Beyond. Journal of Economic Perspectives 19(2):99-120.

Lessig, L. 2004. The Creative Commons. The Montana Law Review 65(1):1-14.

Lindsay, C. M. and W. R. Dougan. 2013. Efficiency in the Provision of Pure Public Goods by Private Citizens. Public Choice 156(1/2):31-43.

Madison, M. J., B. M. Frischmann and K. J. Strandburg. 2010. Constructing Commons in the Cultural Environment. Cornell Law Review 95:657.

Martin, S. and J. Scott. 2000. The Nature of Innovation Market Failure and the Design of Public Support for Private Innovation. Research Policy 29(4-5):437-47.

Mazzucato, M. 2013. The Entrepreneurial State: Debunking Public vs. Private Sector Myths. London: Anthem Press.

Mises, L. von. 1949. Human Action: A Treatise on Economics. New Haven: Yale University Press.

Murphy, K. M., A. Shleifer and R. W. Vishny. 1993. Why is Rent-seeking so Costly to Growth? The American Economic Review 83(2)409-414.

Nelson, R. R. 1959. The Simple Economics of Basic Scientific Research. Journal of Political Economy 67:296307.

Nelson, R. R. 1993. National Innovation Systems: A Comparative Analysis. University of Illinois at UrbanaChampaign's Academy for Entrepreneurial Leadership Historical Research Reference in Entrepreneurship.

Nuvolari, A. 2004. Collective Invention During the British Industrial Revolution: The Case of the Cornish Pumping Engine. Cambridge Journal of Economics 28:347-63.

Olson, M. 1982. The Rise and Decline of Nations: Economic Growth, Stagflation, and Social Rigidities. Yale University Press.

Ostrom, E. 1990. Governing the Commons: The Evolution of Institutions for Collective Action. Cambridge: Cambridge University Press.

Ostrom, E. 2005. Understanding Institutional Diversity. Princeton, NJ: Princeton University Press. 
Ostrom, E. and C. Hess. 2006. A Framework for Analyzing the Knowledge Commons. In Understanding Knowledge as a Commons: from Theory to Practice. eds. Hess, C. and E. Ostrom, 41-82. Cheltenham: Edward Elgar.

Polyani, K. 1944. The Great Transformation. New York: Rinehart.

Rumelt, R. P. 2005. Theory, Strategy, and Entrepreneurship. In Handbook of Entrepreneurship Research eds. Alvarez, S. A., Agrawal, R. and O. Sorenson, 11-32. Springer.

Rogers, E. 2003. Diffusion of Innovations. 5th ed. New York: Free Press.

Romano, R. E. 1989. Aspects of R\&D Subsidization. The Quarterly Journal of Economics 104(4):863-873.

Sarasvathy, S. D., N. Dew, S. R. Velamuri and S. Venkataraman. 2010. Three Views of Entrepreneurial Opportunity. In Handbook of Entrepreneurship Research, 77-96. New York: Springer.

Schultz, T. W. 1980. Investment in Entrepreneurial Ability. The Scandinavian Journal of Economics 82(4):437448.

Schumpeter, J. A. 1934. The Theory of Economic Development: An Inquiry Into Profits, Capital, Credit, Interest, and the Business Cycle. (Vol. 55), Transaction Publishers.

Schumpeter, J. A. 1942. Capitalism, Socialism and Democracy. New York: Harper \& Row.

Shackle, G. L. S. 1972. Epistemics and Economics. Transaction Publishers.

Shane, S. A. 2000. A General Theory of Entrepreneurship: The Individual-Opportunity Nexus. Edward Elgar Publishing.

Shane, S. A. 2000b. Prior Knowledge and the Discovery of Entrepreneurial Opportunity. Organizational Science 11(4):448-469.

Shane, S. A. and S. Venkataraman. 2000. The Promise of Entrepreneurship as a Field of Research. Academy of Management Review 25(1):217-226.

Shleifer, A. and R. W. Vishny. 2002. The Grabbing Hand: Government Pathologies and Their Cures. Harvard: Harvard University Press.

Singh, R. P. 1998. Entrepreneurial Opportunity Recognition Through Social Networks. New York: Garland.

Soete, L., B. Verspagen and B. ter Weel. 2010. Systems of Innovation. In Handbook of the Economics of Innovation eds. Hall, B. H. and N. Rosenberg, 2:1159-1180.

Stark, D. 2009. The Sense of Dissonance: Accounts of Worth in Economic Life. Princeton, NJ: Princeton University Press.

Stephan, P. 1996. The Economics of Science. Journal of Economic Literature 34:1199-235.

Stigler, G. J. 1971. The Theory of Economic Regulation. The Bell Journal of Economics and Management Science 2(1):3-21.

Venkataraman, S. 1997. The Distinctive Domain of Entrepreneurship Research. Advances in Entrepreneurship, Firm Emergence and Growth 3(1):119-138.

von Hippel, E. 1986. Lead Users: A Source of Novel Product Concepts. Management Science 32(7):791-805.

von Hippel, E. 2007. Horizontal Innovation Networks-By and For Users. Industrial and Corporate Change 16(2):293-315.

von Hippel, E. and G. von Krogh. 2003. Open Source Software Development and the Private-Collective Innovation Model: Issues for Organization Science. Organization Science 14(2):208-23.

von Krogh, G., S. Haefliger, S. Spaeth and M. Wallin. 2012. Carrots and Rainbows: Motivation and Social Practice in Open Source Software Development. MIS Quarterly 36:649-76. 